\title{
Desain LKPD Fisika Berorientasi Al-Qur'an dengan Strategi Inkuiri Terbimbing terhadap Pencapaian Kompetensi Peserta Didik SMA/MA
}

\author{
Artha Nesa Chandra ${ }^{1 *}$, Siti Haryati ${ }^{1}$, Venny Haris ${ }^{1}$ \\ ${ }^{1}$ Jurusan Tadris Fisika Fakultas Tarbiyah dan Ilmu Keguruan IAIN Batusangkar \\ Jalan Sudirman No. 137 Lima Kaum, Kabupaten Tanah Datar, Sumatera Barat \\ *Email: arthanesachandra@iainbatusangkar.ac.id
}

\author{
Article History \\ Received: 1 Juni 2020 \\ Reviewed: 19 Juni 2020 \\ Published: 30 Juni 2020

\section{Key Words} \\ Teaching Material; LKPD; \\ Qur'an Oriented; Guided \\ Inquiry; Learning \\ Competencies.
}

\begin{abstract}
Mostly, teaching materials merely focus on formulas and theories, yet there has not been found any teaching materials oriented to Qur'an. Due to that reason, it is significant to provide materials enabling students to learn independently, especially, those correlating the physics materials with Qur'an. Therefore, this study aimed to produce students' worksheets of physics, known as LKPD, correlating Qur'an with Guided Inquiry to achieve the students' competencies, particularly, in the topic of equilibrium and rotational dynamics. This study employed the Research and Development design with the 4-D research model consisting of four stages, namely defining, designing, developing, and disseminating. This LKPD also contains six stages of Guided Inquiry, namely orientation, formulating problems, formulating hypotheses, collecting data, testing hypotheses, and formulating conclusions. Every stage of Guided Inquiry engages the Qur'an verses with the material. The findings showed the validity of LKPD was at $88 \%$ categorized as very valid. The questionnaires resulted $88 \%$ of teachers and $70.3 \%$ of students categorized as very practical and practical. The average post-test score for students' competence (82.45) is higher than the average pre-test score (49.64) and $\mathrm{N}$-gain of 0.77 considered high and effective. In conclusion, the physics students' worksheet or LKPD which employed Guided Inquiry corresponding with Qur'an is considered valid, practical, and effective to promote students in learning physics.
\end{abstract}

\section{PENDAHULUAN}

Al-Qur'an merupakan sarana dalam mendekatkan diri kepada Allah SWT dan meraih kecintaanNya. Al-Qur'an ibarat lautan ilmu yang tidak ada batasnya. Ayat Al-Qur'an yang pertama diturunkan yaitu surat Al-Alaq Ayat
1-5 dan Az-Zumar Ayat 9 membahas mengenai perintah mempelajari ilmu pengetahuan (Cahyati \& Suseno, 2015). Ilmu yang kita pelajari pada dasarnya bersumber pada AlQur'an. Segala sesuatu yang terdapat di jagat raya ini telah tertuang dalam Al-Qur'an. 
Kita sebagai umat Muslim yang memiliki akal pikiran dituntut untuk mempelajari semua ciptaan Allah SWT serta mengajarkannya guna kemaslahatan umat manusia, sehingga kecintaan dan kebanggaan terhadap Al-Qur'an tidak akan pernah pudar. Hal ini sesuai dengan Sabda Nabi Muhammad SWA dalam hadist yang diriwayatkan oleh Bukhari (5027) dan Abu Daut (1452) dalam (Al-Qarni, 2005).

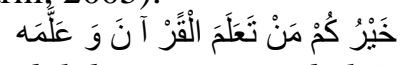

"Sebaik-baik kalian adalah orang yang belajar Al-Qur'an dan mengajarkannya". Maksudnya, demi Allah, bahwa orang yang terbaik, termulia dan teragung diantara kalian adalah mereka yang hidup dengan bimbingan Al-Qur'an". Oleh karena itu pengintegrasian Al-Qur'an dalam pengembangan ilmu pengetahuan khususnya fisika sangatlah penting untuk dilakukan oleh seorang guru.

Ilmu akan bermanfaat secara utuh dan menjadi hal yang luar biasa, apabila ilmu tersebut dikembangkan dan diajarkan. Fisika sebagai salah satu bentuk ilmu alam, membahas semua gejala alam baik yang bersifat mikroskopik maupun makroskopik. Oleh karena itu proses pembelajaran harus diarahkan agar peserta didik mampu mengatasi setiap tantangan dan rintangan melalui sejumlah kompetensi yang harus dimiliki (Chotimah \& Fathurrohman, 2018). Kompetensi merupakan kemampuan peserta didik yang tertuang pada Standar Nasional Pendidikan berupa sikap, pengetahuan, dan keterampilan (Permendikbud, 2016). Proses untuk mengukur ketercapaian kompetensi peserta didik dalam pembelajaran ini disebut dengan ulangan (Permendikbud, 2016). Ulangan dapat berupa Ulangan Harian (UH) juga Ulangan Tengah Semester (UTS) serta Ulangan Akhir Semester (UAS). Agar proses ini dapat berjalan dengan baik, efektif dan efisien maka guru harus membuat perencanaan. Perencanaan ini diantaranya adalah pemilihan media dan strategi pembelajaran yang tepat.

Media pembelajaran merupakan alat menyalurkan/menyampaikan pesan/informasi (Munadi, 2013). Media ini menimbulkan gairah belajar, memungkinkan peserta didik belajar mandiri sesuai dengan kemampuan visual, auditory dan kinestetik, serta memberikan ransangan yang sama (Chotimah \& Fathurrohman, 2018). Di dalam Al-Qur'an kita juga dianjurkan untuk mencari jalan/media terbaik agar memudahkan diri untuk mendekatkan diri dan memperoleh ilmu Allah SWT, seperti yang tergambar dalam surat AlMaidah ayat 35. Salah satu contoh media pembelajaran ini adalah Lembar Kegiatan Peserta Didik (LKPD). LKPD merupakan tugastugas terstruktur yang harus dikerjakan peserta didik berupa lembaran-lembaran (Putra, 2017).

Selain media, pemilihan strategi pembelajaran yang tepat juga mempengaruhi pencapaian tujuan pembelajaran. Strategi pembelajaran adalah cara-cara yang akan digunakan oleh guru untuk memilih kegiatan belajar yang akan digunakan selama proses pembelajaran (Uno, 2008). Pemilihan ini harus mempertimbangkan situasi kondisi, sumber belajar, kebutuhan dan karakteristis dari peserta didik.

Berdasarkan observasi dan wawancara yang peneliti lakukan di SMA N 1 Batusangkar, diperoleh informasi bahwa kemampuan peserta didik dalam pembelajaran fisika sangat beragam, ditambah dengan rendahnya kemampuan awal dan sulitnya peserta didik dalam memahami konsep fisika. Ini tergambar pada hasil Ulangan Harian Materi Kesetimbangan dan Dinamika Rotasi peserta didik di SMAN 1 Batusangkar Kelas XI MIPA pada Tabel 1. Kemampuan peserta didik berdasarkan Tabel 1 masih tergolong rendah karena persentase ketuntasan peserta didik tidak mencapai $50 \%$.

Tabel 1. Nilai UH Materi Kesetimbangan dan Dinamika Rotasi

\begin{tabular}{lccc}
\hline \multirow{2}{*}{ Kelas } & \multirow{2}{*}{ Jumlah Peserta Didik } & \multicolumn{2}{c}{ Persentase Ketuntasan (\%) } \\
\cline { 3 - 4 } & & Tuntas & Tidak Tuntas \\
\hline MIPA 1 & 26 & 7.7 & 92.3 \\
MIPA 2 & 26 & 15.4 & 84.6 \\
MIPA 3 & 26 & 11.5 & 88.5 \\
MIPA 4 & 26 & 30.8 & 69.2 \\
MIPA 5 & 26 & 15.4 & 84.6 \\
MIPA 6 & 26 & 26.9 & 73.1 \\
\hline \multicolumn{3}{c}{ Sumber: Guru Fisika SMA N 1 Batusangkar }
\end{tabular}


Peserta didik juga sulit memahami konsep fisika dan menganalisa soal-soal fisika. Mereka beranggapan bahwa fisika itu sulit dan materinya berisi rumus-rumus yang sulit sehingga mereka menjadi pesimis dalam mempelajari fisika. Padahal dalam proses pembelajaran mereka sudah dibekali dengan LKPD, tetapi LKPD ini masih bersifat monoton karena isinya hanya materi, rumus-rumus dan soal-soal saja. LKPD ini juga sangat kurang dalam menuntun peserta didik untuk memecahkan masalah atau menemukan konsep melalui aktivitas mandiri, apalagi pembahasan mengenai integrasi $\mathrm{Al}$ Qur'an dengan materi pembelajaran.

Dewasa ini, peran guru sudah mulai dikesampingkan karena peserta didik dapat belajar di mana saja dan kapan saja secara mandiri sesuai minat dan gaya belajar. Oleh karena itu, dibutuhkan bahan ajar seperti LKPD yang dapat menuntun peserta didik dalam memecahkan masalah secara mandiri. Selain itu juga dibutuhkan LKPD yang berorientasi AlQur'an yang mengkaitkan materi fisika dengan kandungan Al-Qur'an sehingga menambah pemahaman dan keyakinan siswa terhadap kebesaran Allah SWT.

Selain media pembelajaran, agar tujuan pembelajaran dapat tercapai dengan optimal sesuai dengan kompetensi yang diharapkan, diperlukan juga strategi pembelajaran. Strategi Inkuiri Terbimbing merupakan salah satu strategi yang tepat digunakan. Mengunakan strategi ini peserta didik diyakini lebih aktif, bebas merumuskan pemikiran atau ide-idenya, dan mandiri. Strategi ini memiliki enam langkah pembelajaran yaitu: 1) orientasi, 2) merumuskan masalah, 3) merumuskan hipotesis, 4) mengumpulkan data, 5) menguji hipotesis, 6) merumuskan simpulan (Suyadi, 2013).

Oleh karena itu peneliti mendesain sebuah LKPD dengan judul "Desain LKPD Fisika Berorientasi Al-Qur'an dengan Strategi Inkuiri Terbimbing terhadap Pencapaian Kompetensi Peserta didik SMA/MA pada Materi Keseimbangan dan Dinamika Rotasi”. Sebelumnya telah dilakukan penelitian oleh (Latifah, Setiawati, \& Basith, 2016) mengenai "Pengembangan LKPD berorientasi Nilai-nilai Agama Islam melalui Pendekatan Inkuiri Terbimbing" yang berkategori valid dengan nilai validasi dari ahli materi $85 \%$, ahli materi agama Islam $89 \%$, ahli desain $91 \%$. Untuk respon guru dan peserta didik diperoleh nilai masing-masing
$84 \%$ dan $90 \%$. Perbedaan penelitian ini dengan yang peneliti lakukan dari segi materi yang diangkat dan cakupan penelitian. Pada penelitian terdahulu mengangkat Materi Suhu dan Kalor sedangkan peneliti mengangkat Materi Kesetimbangan dan Dinamika Rotasi. Untuk cakupan penelitian, penelitian terdahulu terbatas pada validitas dan kepraktisan saja, tetapi pada penelitian yang peneliti lakukan prosesnya sampai pada tahap efektivitas.

\section{METODE PENELITIAN}

Research and Development adalah metoda yang digunakan pada penelitian ini, sehingga dihasilkan suatu produk dan nilai keefektifan dari produk tersebut (Sugiyono, 2011). Produk yang peneliti kembangkan berupa LKPD fisika berorientasi Al-Qur'an dengan Strategi Inkuiri Terbimbing terhadap pencapaian kompetensi peserta didik SMA/MA pada Materi Kesetimbangan dan Dinamika Rotasi. Prosedur pengembangan penelitian ini mengacu kepada model pengembangan yang disarankan oleh Thiagarajan dan Sammel dalam Trianto yaitu 4D yang terdiri dari 4 tahap pengembangan, yaitu: Define, Design, Develope dan Disseminate (Trianto, 2010). Tetapi karena keterbatasan biaya dan waktu, maka tahap Disseminate tidak dilakukan. Subjek uji coba adalah peserta didik kelas XI SMA N 1 Batusangkar. Design one group pretest-postest pada satu kelas (28 orang) yaitu XI MIPA 4 di SMA N 1 Batusangkar merupakan rancangan yang digunakan dalam penelitian ini.

Instrumen pengumpulan data berupa: 1) lembar validasi LKPD, 2) lembar angket respon, dan 3) soal tes awal (pretest) dan tes akhir (posttest). Tes digunakan untuk memperoleh hasil belajar peserta didik. Soal tes terlebih dahulu divalidasi dan diuji coba kepada siswa di kelas XI MIPA 3 SMAN 1 Batusangkar sebanyak 36 orang. Instrumen dan produk yang dihasilkan sebelum digunakan terlebih dahulu divalidasi oleh 3 orang pakar yang terdiri dari 1 orang dosen pendidikan, 1 orang dosen tafsir dan dan 1 orang guru fisika. Jenis data yang diperoleh yaitu: a) data kualitatif, berupa data hasil validasi LKPD, dan b) data kuantitatif berupa data hasil praktikalitas LKPD yang diperoleh melalui angket respon peserta didik 
dan guru, sedangkan data hasil efektivitas diperoleh berdasarkan nilai tes peserta didik.

\section{HASIL DAN PEMBAHASAN}

\section{Tahap Pendefinisian (Define)}

Tahap ini dilakukan untuk mendapatkan gambaran umum mengenai permasalahan yang terdapat di sekolah, melalui: 1) wawancara dengan guru fisika SMAN 1 Batusangkar, 2) melakukan analisa silabus pembelajaran fisika Kelas XI SMA Semester I, 3) melakukan analisa bahan ajar dan buku teks yang dipakai guru fisika di kelas XI SMA sebagai sumber belajar peserta didik dan mereview literatur tentang LKPD.

Informasi yang peneliti peroleh dari hasil wawancara adalah guru telah menggunakan buku paket dan LKPD tetapi belum berorientasikan Al-Qur'an. Penjelasan materi yang terdapat dalam LKPD terfokus kepada rumus, soal dan belum ada penerapan strategi serta integrase Al-Qur'an. Sedangkan metode yang digunakan guru dalam proses pembelajaran sudah bervariasi tidak hanya metode ceramah, tetapi juga menggunakan metode eksperimen pada materi tertentu.

Berdasarkan analisis silabus mata pelajaran fisika kelas XI, peserta didik masih kesulitan memahami Materi Kesetimbangan dan Dinamika Rotasi. Materi ini banyak mengaplikasikan rumus sehingga peserta didik sulit memecahkan masalah terutama pada peserta didik yang memiliki kemampuan di bawah rata-rata. Peserta didik juga kurang memahami konsep Titik Berat Benda.

Berdasarkan hasil analisa buku teks dan LKPD yang dirancang oleh guru di sekolah memiliki kelemahan diantaranya: 1) lebih menonjolkan materi, soal-soal serta rumus sehingga membosankan. 2) masih menggunakan bahasa dan simbol fisika yang disusun dalam konteks yang jauh dari realitas kehidupan peserta didik dan tidak bisa memecahkan masalah dalam kehidupan sehari-hari peserta didik. 3) kurang sesuai dengan karakteristik peserta didik.

Dari analisisa yang dilakukan pada tahap pendefinisian, LKPD merupakan sumber belajar yang dikembangkan guru. Keberadaan LKPD diharapkan dapat membantu peserta didik agar termotivasi dan aktif serta membantu memahami materi sendiri di rumah.

\section{Tahap Perancangan (Design)}

Tahap perancangan dilakukan dengan menyiapkan materi Kesetimbangan dan Dinamika Rotasi yang akan ditampilkan pada LKPD. LKPD ini dirancang menggunakan aplikasi Corel Draw X 7. Setelah materi disusun kemudian ditelaah ayat-ayat Al-Qur'an yang sesuai dengan materi dan diteruskan dengan merancang bagian-bagian LKPD dengan mengacu kepada Strategi Inkuiri Terbimbing.

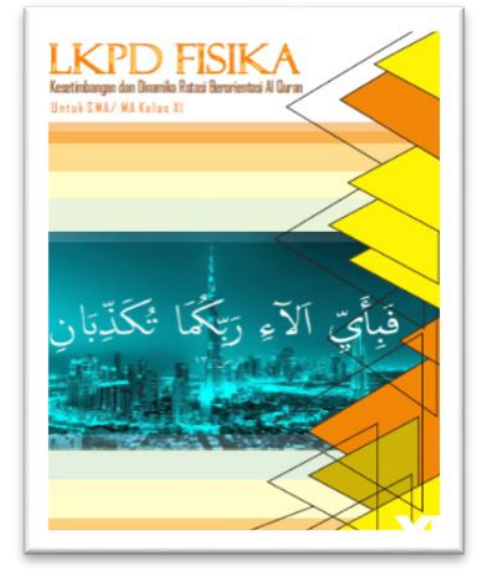

Gambar 1. Cover LKPD

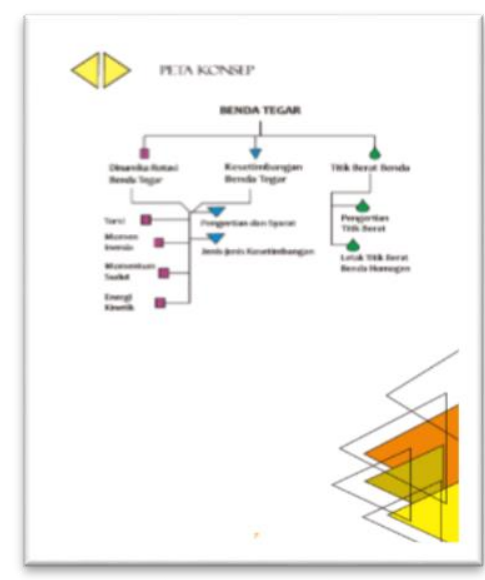

Gambar 2. Peta konsep 


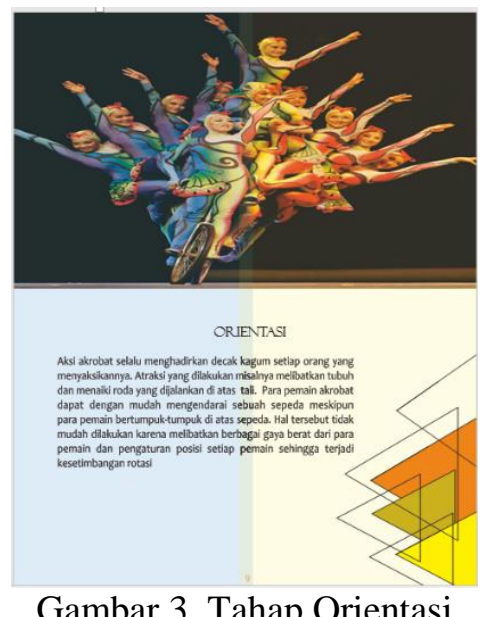

Gambar 3. Tahap Orientasi

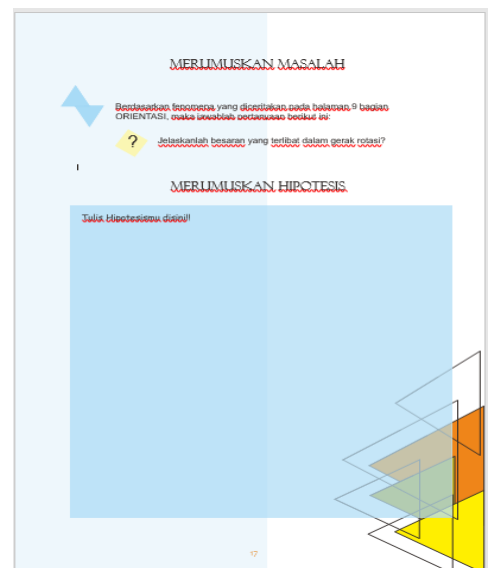

Gambar 4. Tahap Merumuskan Masalah
Pada bagian pendahuluan LKPD berisi kata pengantar. Selain itu juga terdapat daftar isi, daftar tabel, KI, KD, indikator, peta konsep yang menggambarkan isi LKPD. Penyampaian materi pada LKPD ini dikemas dalam tiga bagian yang disebut dengan "Fokus" yaitu Fokus 1 mengenai Dinamika Rotasi, Fokus 2 mengenai Kesetimbangan dan Fokus 3 mengenai Titik Berat Benda. Karakteristik LKPD fisika berorientasi Al-Qur'an dengan Strategi Inkuiri Terbimbing tergambar sebagai berikut:

a. Cover

Pada LKPD dilengkapi dengan gambar yang menunjukkan isi dari materi LKPD juga pada cover diberi gambar potongan ayat AlQur'an, yang menjadi cerminan bahwa LKPD ini berorientasi Al-Qur'an. Tampilan cover LKPD yang dikembangkan seperti Gambar 1 .

b. Peta Konsep

LKPD memuat "Peta Konsep" yang menggambarkan penjelasan materi dalam LKPD fisika. Peta Konsep merupakan skema atau ringkasan materi pelajaran. Peta Konsep dapat digunakan untuk membantu peserta didik dalam menyusun konsep dan menghindari miskonsepsi. Dimana konsep ini merupakan dasar berfikir sehingga nantinya dapat memecahkan masalah. Contoh Peta konsep yang dikembangkan seperti Gambar 2.

c. Fokus

Merupakan suatu cara bagi peneliti untuk membagi penjelasan materi di dalam LKPD. LKPD terdiri dari "Fokus 1, 2 dan 3". Pada masing-masing fokus memiliki tahapan Inkuri Terbimbing dalam penjelasan materi. Untuk Strategi Inkuiri Terbimbing dilihat contoh penyajiannya bagian "Tahap Orientasi" pada Gambar 3 dan "Tahap Merumuskan Masalah" pada Gambar 4.

Dengan adanya strategi inkuiri terbimbing ini peserta didik dapat mencari dan menyelidiki secara sistematis, kritis, logis, dan analitis, merumuskan sendiri penemuannya dengan penuh percaya diri dan menuntun peserta didik dalam memahami konsep serta melatih kemandirian. Pada fokus juga terdapat penjelasan Al-Qur'an serta Motivasi yang sesuai dengan materi. Penyampaiannya dikemas dalam bentuk "Telusuri Al-Qur'an" dan "Vitamin Hati" seperti Gambar 5.

Pada telusur Al-Qur'an, contohnya Materi Dinamika Rotasi dijabarkan kaitannya dengan surat Yasin ayat 38. Ayat ini membahas tentang perputaran matahari yang terjadi pada porosnya. Contoh lain orientasi Ayat Al-Qur'an pada Materi Keseimbangan dibahas pada surat Al Qashash ayat 77. Dijelaskan bahwa kesetimbangan tidak hanya dibutuhkan dalam membangun gedung agar berdiri kokoh, namun untuk membangun pribadi yang kokoh juga dibutuhkan keseimbangan. 


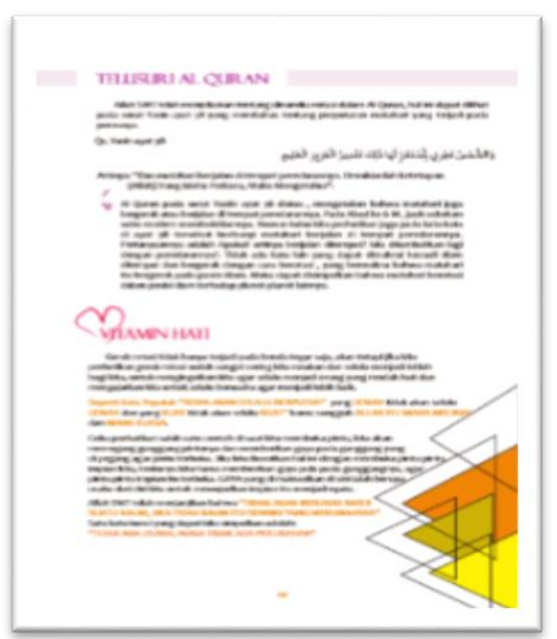

Gambar 5. Telusuri Al-Qur'an dan Vitamin Hati

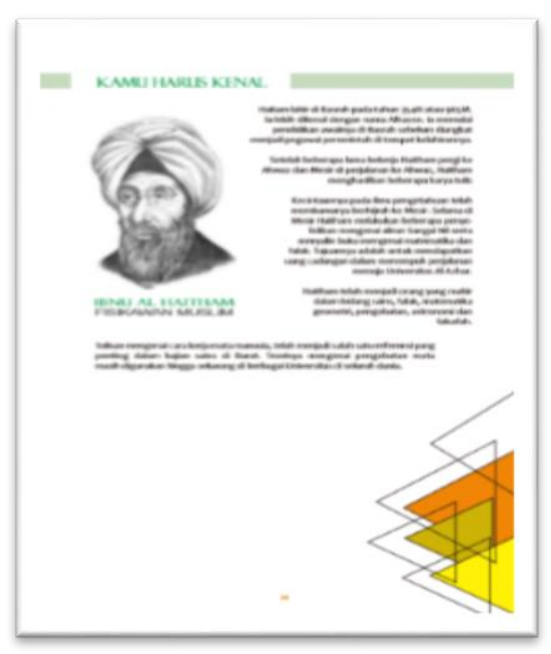

Gambar 6. Кати Harus Kenal

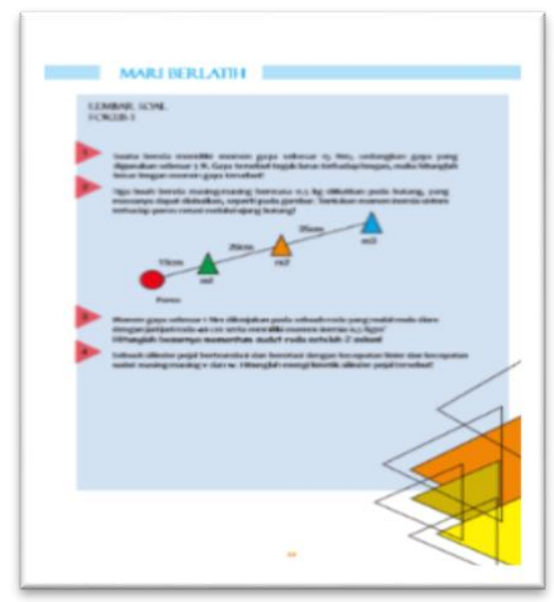

Gambar 7. Mari Berlatih

Tabel 2. Hasil Validasi LKPD Fisika Berorientasi Al-Qur'an dengan Strategi Inkuiri Terbimbing

\begin{tabular}{|c|c|c|c|c|c|c|c|c|}
\hline \multirow{2}{*}{ No } & \multirow{2}{*}{ Aspek } & \multicolumn{3}{|c|}{ Validator } & \multirow[t]{2}{*}{ Jumlah } & \multirow[t]{2}{*}{ Skor Max } & \multirow[t]{2}{*}{$\%$} & \multirow[t]{2}{*}{ Ket } \\
\hline & & 1 & 2 & 3 & & & & \\
\hline 1 & Isi LKPD & 49 & 54 & 51 & 154 & 168 & 91 & Sangat Valid \\
\hline 2 & Format LKPD & 25 & 25 & 26 & 76 & 84 & 90 & Sangat Valid \\
\hline 3 & Bahasa & 19 & 18 & 19 & 56 & 72 & 77 & Valid \\
\hline \multicolumn{2}{|c|}{ Jumlah } & 93 & 97 & 96 & 286 & 324 & 88 & Sangat Valid \\
\hline
\end{tabular}

Selain itu di dalam Fokus juga terdapat info tentang ilmuan fisika. Info ini diharapkan dapat membantu menambah wawasan peserta didik tentang fisika yang dikemas dalam bentuk "Kamu Harus Kenal" yang tampilannya seperti Gambar 6.

d. Latihan Soal.

Latihan soal ini disediakan pada setiap materi. Latihan soal ini dikemas dalam bentuk "Mari Berlatih" tampilannya seperti Gambar 7.
Untuk menyelesaikan latihan juga disediakan lembar jawaban di dalam LKPD.

LKPD ini didesain dengan tampilan/bagian-bagian yang bervariasi ini bertujuan agar peserta didik tidak pasif, menimbulkan kegairahan belajar dan dapat belajar mandiri sesuai minatnya. Hal ini sesuai dengan pendapat dari (Uno, 2008) bahwa penggunaan media secara tepat dan bervariasi dapat mengatasi sifat pasif peserta didik. 
3. Tahap Pengembangan (Develop)

a. Hasil Validasi LKPD Fisika Berorientasi Al-Qur'an dengan Strategi Inkuiri Terbimbing.

Produk LKPD yang telah dirancang selanjutnya divalidasi. Berdasarkan validasi oleh tiga orang validator diperoleh data seperti pada Tabel 2. Pada Tabel 2 terlihat hasil analisa data rata-rata validasi LKPD fisika berorientasi AlQur'an dengan Strategi Inkuiri Terbimbing tergolong sangat valid dengan persentase $88 \%$. Validasi ini diperoleh dari aspek isi, aspek format LKPD dan aspek Bahasa. Ditinjau dari Aspek Isi, LKPD ini memiliki persentase 91\% berkategori sangat valid. Aspek Format LKPD persentase $90 \%$ berkategori sangat valid, dan Aspek Bahasa persentase $77 \%$ berkategori valid.

Hasil ini diperoleh berdasarkan analisa pada aspek isi, LKPD sudah menunjang pencapaian kompetensi peserta didik, salah satunya Kompetensi Inti (KI) 1 . KI 1 yaitu Menghayati dan mengamalkan ajaran agama. Ini diperoleh melalui pembahasan ayat-ayat $\mathrm{Al}$ Qur'an yang terdapat pada LKPD. Dengan menggunakan LKPD ini peserta didik paham mengenai kebesaran Tuhan dan mengamalkan dalam kehidupan sehari-hari sehingga menghasilkan perubahan karakter peserta didik.

Berdasarkan penjabaran materi, LKPD telah sesuai dengan Komptensi Inti (KI) dan Kompetensi Dasar (KD) yang ingin dicapai. Langkah-langkah kegiatan pembelajaran sudah sesuai dengan langkah kegiatan pada Strategi Inkuiri Terbimbing dan pembahasan ayat AlQur'an tentang Materi Kesetimbangan dan Dinamika Rotasi sudah dipaparkan dengan jelas.

Dilihat dari aspek bahasa, LKPD ini menggunakan bahasa yang sederhana, mudah dipahami, dan komunikatif. Pada tahap valiadasi ini, validator juga memberikan saran dan masukan yaitu: a) mengubah ukuran huruf yang terlalu kecil, b) beberapa huruf yang masih tertinggal dalam penulisan, c) Penulisan lebih dirapikan, d) Perbaikan desain LKPD diantaranya: merapikan desain pada daftar isi, memberikan kolom pada bagian rumus, dan memberikan jarak antara tulisan dengan desain.

\section{b. Hasil Uji Praktikalitas LKPD Fisika Berorientasi Al-Qur'an dengan Strategi Inkuiri Terbimbing}

Setelah dilakukan uji validasi, selanjutnya dilakukan uji Praktikalitas. Uji praktikalitas diperoleh berdasarkan penilaian oleh pengguna LKPD yang dikembangkan yaitu guru dan peserta didik berupa angket respon. Berdasarkan angket respon guru diperoleh data uji praktikalitas seperti Tabel 3 sedangkan Tabel 4 merupakan data uji praktikalitas dari angket respon peserta didik.

Berdasarkan data Tabel 3, LKPD ini sangat praktis digunakan guru dalam pembelajaran dengan persentase $88 \%$. Sedangkan berdasarkan data Tabel 4, terlihat bahwa LKPD ini praktis digunakan peserta didik dalam pembelajaran dengan persentase $70,3 \%$. Aspek praktikalitas merupakan salah satu indikator produk yang harus dikembangkan (Pratama, Eliwatis, \& Fajar, 2018). Berdasarkan Aspek Tampilan diperoleh hasil rata-rata respon guru dan peserta didik masing-masing $75 \%$ dan $66,3 \%$ dengan kategori praktis yang artinya LKPD yang dikembangkan menarik digunakan guru dan peserta didik.

Pada uji praktikalitas Aspek pemahaman materi diperoleh kategori praktis dan sangat praktis dengan rata-rata $70,7 \%$ untuk respon peserta didik dan 84\% untuk respon guru. Peserta didik dan guru berpendapat bahwa petunjuk penggunaan LKPD, pertanyaanpertanyaan dalam LKPD mudah dipahami, LKPD mudah digunakan, sehingga memudahkan peserta didik dalam memahami materi. Hal ini sejalan dengan pendapat (Haviz, 2013) bahwa tingkat kepraktisan dilihat dari jawaban pemakai baik guru atau peserta didik yang beranggapan bahwa materi mudah dan dapat digunakan dalam pembelajaran. Begitu juga dalam hal orientasi Al-Qur'an. LKPD memuat penjelasan ayat Al-Qur'an sehingga peserta didik mengetahui dan memahami lebih lanjut tentang materi. Proses pembelajaran yang dirancang di dalam LKPD dapat membuat peserta didik belajar mandiri dan meningkatkan kemampuan daya nalar serta menumbuhkan rasa keingintahuan peserta didik untuk mempelajari fisika lebih lanjut. 
Tabel 3. Data Hasil Uji Praktikalitas dari Angket Respon Guru

\begin{tabular}{clcccc}
\hline No & \multicolumn{1}{c}{ Aspek } & Total Skor & Skor Max & $\%$ & Ket \\
\hline 1 & Tampilan LKPD & 3 & 4 & 75 & Praktis \\
2 & Penggunaan Bahasa & 6 & 8 & 75 & Praktis \\
3 & Pemahaman terhadap materi & 27 & 32 & 84 & Sangat praktis \\
4 & Memuat ayat suci Al-Qur'an & 3 & 4 & 75 & Praktis \\
5 & Memuat tahapan strategi inkuiri terbimbing & 28 & 28 & 100 & Sangat praktis \\
6 & Memuat motivasi untuk belajar & 7 & 8 & 87 & Sangat praktis \\
\hline & Jumlah & 74 & 84 & 88 & Sangat praktis \\
\hline
\end{tabular}

Tabel 4. Data Hasil Uji Praktikalitas dari Angket Respon Peserta Didik

\begin{tabular}{clcccc}
\hline No & \multicolumn{1}{c}{ Aspek } & Total Skor & Skor Max & $\%$ & Ket \\
\hline 1 & Tampilan LKPD & 69 & 104 & 66,3 & Praktis \\
2 & Penggunaan Bahasa & 230 & 312 & 73,7 & Praktis \\
3 & Pemahaman terhadap materi & 809 & 1144 & 70,7 & Praktis \\
4 & Memuat ayat suci Al-Qur'an & 79 & 104 & 75,9 & Praktis \\
5 & Memuat tahapan strategi inkuiri terbimbing & 71 & 104 & 68,2 & Praktis \\
6 & Memuat motivasi untuk belajar & 279 & 416 & 67,1 & Praktis \\
\hline \multicolumn{2}{r}{ Jumlah } & 1537 & 2184 & 70,3 & Praktis \\
\hline
\end{tabular}

Tabel 5. Hasil Mean Pretest dan Posttest

\begin{tabular}{ccc}
\hline No & Ukuran & Nilai \\
\hline 1 & Rata-rata pretest & 49,64 \\
2 & Rata-rata posttest & 82,45 \\
3 & N-gain & 0,77 \\
\hline
\end{tabular}

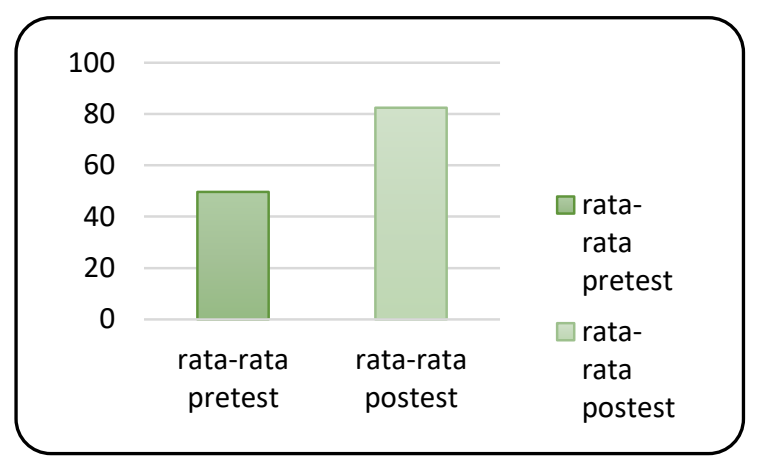

Gambar 8. Grafik Mean Pretest dan Posttest

Dari segi gambar, Bahasa dan desain LKPD membuat peserta didik tidak bosan dan pembelajaran fisika menjadi menyenangkan. Ini terlihat dari sikap antusias peserta didik dalam mengikuti pembelajaran. LKPD yang dirancang telah memenuhi kriteria kepraktisan.

\section{c. Hasil Efektivitas LKPD Fisika Berorientasi Al-Qur'an dengan Strategi Inkuri Terbimbing}

Hasil efektivitas LKPD fisika berorientasi Al-Qur'an dengan Strategi Inkuiri Terbimbing diperoleh berdasarkan uji coba terbatas pada 28 orang peserta didik SMAN 1 Batusangkar di kelas XI MIPA. Uji coba dilakukan berupa pretest dan postest. Hasil mean pretest dan 
posttest tersebut dibandingkan dengan mencari nilai normal gain (N-gain) seperti Tabel 5.

Perbedaan mean antara pretest dan posttest dapat dilihat pada Gambar 8

Berdasarkan data pada Tabel 5 terlihat bahwa mean posttest lebih tinggi dibandingkan mean pretest, dengan nilai n-gainnya 0,77. Artinya LKPD fisika berorientasi Al-Qur'an efektif digunakan dalam proses pembelajaran. LKPD dikatakan efektif jika pembelajaran yang dilakukan dengan bantuan LKPD dapat memotivasi, meningkatkan daya nalar, sehingga terjadi peningkatan kompetensi. Keefektivan LKPD ini dilihat pada pemahaman konsep peserta didik yang mengalami peningkatan pada nilai posttest dibandingkan dengan pretest. Karena penggunaan LKPD menimbulkan semangat dalam diri peserta didik untuk belajar lebih aktif, mau bekerja sama yang dilakukan selama percobaan dan tugas kelompok, serta tingginya rasa ingin tahu yang peserta didik yang ditunjukkan selama PBM.

Kompetensi yang tercapai pada proses pembelajaran menggunakan LKPD fisika berorientasi Al-Qur'an dengan Strategi Inkuiri Terbimbing tidak hanya pada kompetensi pengetahuan saja, tetapi juga mempengaruhi kompetensi sikap dan keterampilan. Kompetensi sikap berupa perubahan kemampuan daya nalar peserta didik sehingga menumbuhkan rasa keingintahuan untuk mempelajari fisika lebih lanjut. Begitu juga pada waktu melakukan percobaan secara berkelompok. Peserta didik saling bekerja sama dengan temannya, meningkatkan rasa ingin tahu dan aktif. Keaktifan ini ditandai dengan banyaknya peserta didik yang mengajukan pertanyaan mengenai materi pembelajaran.

(Rusman, 2012) menyatakan bahwa: "pembelajaran dapat dikatakan efektif jika mampu memberikan pengalaman baru kepada peserta didik membentuk kompetensi peserta didik, serta mengantarkan mereka ke tujuan yang ingin dicapai secara optimal". Dari pernyataan ini dapat dikatakan bahwa LKPD fisika berorientasi Al-Qur'an dengan Strategi Inkuiri Terbimbing efektif untuk digunakan dalam proses pembelajaran fisika pada Materi Kesetimbangan dan Dinamika Rotasi.

\section{KESIMPULAN}

Kesimpulan yang diperoleh berdasarkan Desain LKPD fisika berorientasi Al-Qur'an dengan Strategi Inkuiri Terbimbing pada materi Kesetimbangan dan Dinamika Rotasi kelas XI SMA/MA adalah:

1) Berkategori sangat valid dengan persentase $88 \%$ dari aspek isi dan konstruk.

2) Kategori sangat praktis berdasarkan angket respon guru dengan persentase kepraktisan $88 \%$, serta berkategori praktis berdasarkan angket respon peserta didik dengan persentase kepraktisan 70,3\%.

3) Berkategori efektif diperoleh berdasarkan nilai n-gain 0,77 kreteria tinggi dari perhitungan nilai pretest dan posttest peserta didik.

Maka dapat dikatakan bahwa LKPD yang didesain valid, praktis dan efektif, dapat digunakan dalam pembelajaran fisika untuk meningkatkan kompetansi peserta didik.

\section{DAFTAR KEPUSTAKAAN}

Al-Qarni, A. A. (2005). Jangan Takut Hadapi Hidup. Jakarta: Cakrawala Publishing.

Cahyati, F., \& Suseno, N. (2015). Pengembangan LKS Materi Listrik Statis Berorientasi Nilai Al-Qur'an untuk Siswa Kelas IX Sekolah Muhammadiyah. Jurnal Pendidikan Fisika, 3(2), 60-68. Retrieved from

http://ojs.fkip.ummetro.ac.id/index.php/fis ika/article/view/252

Chotimah, C., \& Fathurrohman, M. (2018). Paradigma Baru Sistem Pembelajaran dan Teori, Metoda, Model, Media hingga Evaluasi Pembelajaran. Yogyakarta: ArRuzz Media.

Haviz, M. (2013). Research and Development; Penelitian di Bidang Kependidikan yang Inovatif, Produktif dan Bermakna. Ta'dib, 16(1), 28-43.

Latifah, S., Setiawati, E., \& Basith, A. (2016). Pengembangan Lembaran Kerja Peserta Didik (LKPD) Berorientasi Nilai-Nilai Agama Islam melalui Pendekatan Inkuiri Terbimbing pada Materi Suhu dan Kalor. Jurnal Ilmiah Pendidikan Fisika AlBiRuNi, 05(1), 43-51. 
https://doi.org/10.24042/jpifalbiruni.v5i1. 104

Munadi, Y. (2013). Media Pembelajaran Sebuah Pendekatan Baru. Jakarta: Referensi (GP Press Group).

Permendikbud. (2016). Permendikbud Nomor 21 Tahun 2016 tentang Standar Isi pendidikan Dasar dan Mengengah.

Pratama, H., Eliwatis, \& Fajar, N. (2018). Pengembangan Modul Pembelajaran Biologi Berbasis Android pada Materi Sistem Regulasi untuk Siswa SMA/MA. Sainstek: Jurnal Sains dan Teknologi. Sainstek: Jurnal Sains Dan Teknologi, 10(2), 43-55. Retrieved from http://ecampus.iainbatusangkar.ac.id/ojs/in dex.php/sainstek/article/view/1202

Putra, A. (2017). Buku Ajar Perencanaan Pembelajaran Fisika. Padang: Sukabina Press. http://repository.unp.ac.id/id/eprint/19215

Rusman. (2012). Model-model Pembelajaran Mengembangkan Profesional Guru. Jakarta: Raja Grafindo Persada.

Sugiyono. (2011). Metode Penelitian Kuantitatif Kualitatif dan R\&D. Bandung: Alfabeta.

Suyadi. (2013). Strategi Pembelajaran Pendidikan Karakter. Bandung: Remaja Rosdakarya.

Trianto. (2010). Model Pembelajaran Terpadu: Konsep, Strategi dan Implementasinya dalam Kurikulum Tingkat Satuan Pendidikan (KTSP). Jakarta: Bumi Aksara. Uno, H. B. (2008). Model Pembelajaran Menciptakan Proses Belajar Mengajar yang Kreatif dan Efisien. Jakarta: Bumi Aksara. 